\title{
Ectonucleotidase activities in Sertoli cells from immature rats
}

E.A. Casali, T.R. da Silva, D.P. Gelain, G.R.R.F. Kaiser,

A.M.O. Battastini,

J.J.F. Sarkis and

E.A. Bernard Departamento de Bioquímica, Instituto de Ciências Básicas da Saúde,
Universidade Federal do Rio Grande do Sul, Porto Alegre, RS, Brasil

\section{Correspondence}

E.A. Bernard

Departamento de Bioquímica

Rua Ramiro Barcellos, 2600, Anexo

90035-003 Porto Alegre, RS

Brasil

Fax: +55-51-316-5540

E-mail: elenbern@ vortex.ufrgs.br

Received September 6, 2000

Accepted July 2, 2001

\section{Abstract}

Sertoli cells have been shown to be targets for extracellular purines such as ATP and adenosine. These purines evoke responses in Sertoli cells through two subtypes of purinoreceptors, $\mathrm{P}_{2 \mathrm{Y} 2}$ and $\mathrm{P}_{\mathrm{A} 1}$. The signals to purinoreceptors are usually terminated by the action of ectonucleotidases. To demonstrate these enzymatic activities, we cultured rat Sertoli cells for four days and then used them for different assays. ATP, ADP and AMP hydrolysis was estimated by measuring the Pi released using a colorimetric method. Adenosine deaminase activity (EC 3.5.4.4) was determined by HPLC. The cells were not disrupted after $40 \mathrm{~min}$ of incubation and the enzymatic activities were considered to be ectocellularly localized. ATP and ADP hydrolysis was markedly increased by the addition of divalent cations to the reaction medium. A competition plot demonstrated that only one enzymatic site is responsible for the hydrolysis of ATP and ADP. This result indicates that the enzyme that acts on the degradation of tri- and diphosphate nucleosides on the surface of Sertoli cells is a true ATP diphosphohydrolase (EC 3.6.1.5) (specific activities of $113 \pm 6$ and 21 \pm 2 nmol Pi mg-1 $\mathrm{min}^{-1}$ for ATP and ADP, respectively). The ecto-5'nucleotidase (EC 3.1.3.5) and ectoadenosine deaminase activities (specific activities of $32 \pm 2 \mathrm{nmol} \mathrm{Pi} \mathrm{mg}^{-1} \mathrm{~min}^{-1}$ for AMP and $1.52 \pm$ $0.13 \mathrm{nmol}$ adenosine $\mathrm{mg}^{-1} \mathrm{~min}^{-1}$, respectively) were shown to be able to terminate the effects of purines and may be relevant for the physiological control of extracellular levels of nucleotides and nucleosides inside the seminiferous tubules.

\section{Introduction}

Extracellular purines interact with specific receptors (purinoreceptors) on the surface of cells activating several biological processes (for reviews, see 1-3). Previous studies have demonstrated that adenosine nucleotides can modulate Sertoli cell responses through the purinoreceptors present on these cells (4-10).

The hormonal regulation of Sertoli cell

\section{Key words}

- Sertoli cells

- Purine nucleotides

- ATP diphosphohydrolase

- Ecto-5'-nucleotidase

- Ectoadenosine deaminase functions in the maintenance of spermatogenesis occurs through inhibitory and stimulatory signals. These signals interact for a bimodal regulation of adenyl cyclase with increasing or decreasing cAMP levels. Extracellular ATP interacting with $\mathrm{P}_{2 \mathrm{Y} 2}$ purinoreceptors coupled with $\mathrm{G}_{\mathrm{i}}$ protein modulates the follicle-stimulating hormone (FSH) response in Sertoli cell cultures. This modulation is pertussis toxin-sensitive and decreases the cAMP levels stimulated by FSH (5). In 
the same study, Filippini et al. (5) demonstrated that ATP can activate inositol phospholipid turnover and $\mathrm{Ca}^{2+}$ signaling.

Regarding adenosine, a product of ATP degradation by ectonucleotidases, Rivkees (11) localized and characterized receptors for this structure in rat testis tissue and demonstrated that Sertoli cells have the $\mathrm{P}_{\mathrm{A} 1}$ receptor subtype on the plasma membrane. In testis tissue, the $\mathrm{P}_{\mathrm{Al}}$ receptors inhibit adenylyl cyclase activity $(4,10)$. Adenosine inhibition of the hormonal effects of FSH in Sertoli cells is reversed by pertussis toxin (8). This fact suggests that the regulation of a cyclic nucleotide-dependent pathway is one of the transduction mechanisms by which adenosine regulates the functions of these cells.

The extracellular hydrolysis of ATP to adenosine by ectonucleotidases has been reported for several cell types (12-20). These enzymatic activities can regulate the extracellular concentration of adenine nucleotides and nucleosides modulating their local effects. Degradation of ATP and other nucleotides occurs through a cascade of cell surface-bound enzymes such as ecto-ATPase (EC 3.6.1.3), ectoapyrase/ATP diphosphohydrolase/NTPDase (EC 3.6.1.5), and ecto5 '-nucleotidase (EC 3.1.3.5), resulting in the formation of ADP, AMP and adenosine (21). The presence of apyrase activity has been well demonstrated in a large number of mammalian sources $(12,13,15)$. Apyrase is the enzyme that hydrolyzes ATP and ADP (and other tri- and diphosphate nucleosides) to the monophosphate esters plus inorganic phosphate (Pi), releasing $2 \mathrm{~mol} \mathrm{Pi} / \mathrm{mol} \mathrm{ATP}$ and $1 \mathrm{~mol} \mathrm{Pi} / \mathrm{mol} \mathrm{ADP}$.

Barbacci et al. (22) identified and characterized a possible ecto-ATPase activity in rat Sertoli cells. In the present study, we demonstrate that Sertoli cells in culture are able to promote the hydrolysis of ATP, ADP and AMP and we present evidence for the first time that the enzymes responsible for nucleotide hydrolysis are a true ectoapyrase (ATP and ADP hydrolysis) and an ecto-5'- nucleotidase (AMP hydrolysis). The kinetic parameters for nucleotide hydrolysis and the effect of divalent cations, calcium and magnesium, on enzymatic activities were determined. Moreover, we show that Sertoli cells can control extracellular adenosine levels through ectoadenosine deaminase activity (EC 3.5.4.4).

\section{Material and Methods}

\section{Material}

Culture medium (DMEM/F-12) and soybean trypsin were purchased from Gibco (Grand Island, NY, USA). Lactate dehydrogenase (LDH) kit, soybean trypsin inhibitor I-S, DNase I, collagenase I, hyaluronidase I$\mathrm{S}$, nucleotides, nucleosides and HEPES were obtained from Sigma (St. Louis, MO, USA), FBS from Cultilab Ltda. (São Paulo, SP, Brazil), and 24-well plates from Costar Co. (Cambridge, MA, USA). Tetrabutyl ammonium chloride was purchased from Fluka Chemika (Neu Ulm, Switzerland). All other chemical reagents were of the highest available grade.

\section{Sertoli cell cultures}

Primary cultures of Sertoli cells from 17to 19-day-old Wistar rats were prepared as previously described (23). Briefly, the testis was sequentially digested with $0.25 \%$ trypsin and DNase $(10 \mu \mathrm{g} / \mathrm{ml})$ for $30 \mathrm{~min}$ at $37^{\circ} \mathrm{C}$ to remove the interstitial tissue. The seminiferous tubules obtained were dissociated with collagenase $(1 \mathrm{mg} / \mathrm{ml})$ and hyaluronidase (1 $\mathrm{mg} / \mathrm{ml}$ ) to separate Sertoli cells from myoid and germ cells for centrifugation at $40 \mathrm{~g}$ for $10 \mathrm{~min}$. The cultures were grown to confluence on 24-multiwell plates (approximately $0.6 \times 10^{6}$ cells/well or $100 \mu \mathrm{g}$ protein/well) at $34^{\circ} \mathrm{C}$ in a water-saturated atmosphere with $95 \%$ air and $5 \% \mathrm{CO}_{2}$ in DMEM/F-12 (1:1) with $1 \%$ FBS for $24 \mathrm{~h}$. On the second day of culture, the monolayer was washed with 
Hank's-buffered saline solution and maintained for three days more in serum-free DMEM/F-12 (1:1). On the fourth day of culture, the Sertoli cell monolayers were used for the ectonucleotidase assays. The Sertoli cell cultures were estimated to be more than $95 \%$ pure, as determined by bright light and phase contrast microscopy and alkaline phosphatase cytochemistry (24). Cellular integrity was determined on the basis of LDH activity. The Sertoli monolayers were incubated with reaction medium for $40 \mathrm{~min}$ and then samples were taken for the determination of LDH with a Sigma kit (LD-L 10, catalog No. $228-10$ ) at $37^{\circ} \mathrm{C}$ in a Cobas Mira automatic incubator. LDH activity is reported as unit of enzyme per $\mathrm{mg}$ protein $(\mathrm{U} / \mathrm{mg})$.

\section{Ectonucleotidase assays}

Sertoli cell monolayers were washed three times with the reaction medium containing $135 \mathrm{mM} \mathrm{NaCl}, 5 \mathrm{mM} \mathrm{KCl}, 10 \mathrm{mM}$ glucose and $10 \mathrm{mM}$ HEPES, pH 7.4. The reaction was started by adding the substrate (ATP, ADP or AMP) to the reaction medium containing $135 \mathrm{mM} \mathrm{NaCl}, 5 \mathrm{mM} \mathrm{KCl}, 10 \mathrm{mM}$ glucose and $10 \mathrm{mM}$ HEPES, $\mathrm{pH} 7.4$, plus $\mathrm{CaCl}_{2}$ and/or $\mathrm{MgCl}_{2}$ (1, 2 and $5 \mathrm{mM}$, as indicated) and EDTA (2 mM, as indicated). The final volume was $0.2 \mathrm{ml}$ and incubation was carried out at $34^{\circ} \mathrm{C}$. After incubation, a supernatant sample was taken and mixed with cold trichloroacetic acid to a final concentration of $5 \%$. This mixture was centrifuged for $10 \mathrm{~min}$ at $16,000 \mathrm{~g}$ at $4^{\circ} \mathrm{C}$ and aliquots were taken for the assay of released $\mathrm{Pi}$ according to the procedure of Chan et al. (25). Incubation time and protein concentration were chosen in order to ensure the linearity of the reaction. Controls to correct for nonenzymatic hydrolysis of nucleotides were prepared by measuring the Pi released into the same reaction medium incubated without cells. The possible contamination with Pi released from cultures was avoided by incubating the monolayers in reaction medi- um without nucleotides. The cultures did not present a measurable release of $\mathrm{Pi}$ at any time of incubation. All assays were done in quadruplicate. $K_{\mathrm{m}}$ and $V_{\max }$ were calculated by linear regression and presented graphically by the Eadie-Hofstee plot. The ATP and ADP concentrations for the same hydrolysis rate were obtained from the substrate curve and used to construct the Chevillard competition plot (26).

\section{Adenosine deaminase assay}

On the fourth day of culture, the monolayers were washed three times with adenosine deaminase assay (ADA) buffer consisting of $100 \mathrm{mM} \mathrm{NaCl}, 20 \mathrm{mM} \mathrm{KCl}, 4 \mathrm{mM}$ $\mathrm{MgCl}_{2}, 2 \mathrm{mM} \mathrm{CaCl}_{2}, 10 \mathrm{mM} \mathrm{NaHCO}{ }_{3}, 5$ $\mathrm{mM}$ glucose and $15 \mathrm{mM}$ Tris, $\mathrm{pH} 7.4$ (27). The reaction was started by adding adenosine $(0.15 \mathrm{mM})$ to the same ADA buffer as described above. The final volume was 0.2 $\mathrm{ml}$ and the incubation was carried out at $34^{\circ} \mathrm{C}$. After incubation $(0,30$ and $60 \mathrm{~min})$, the supernatant was taken and maintained on ice. The samples were boiled for $3 \mathrm{~min}$ and centrifuged at $4^{\circ} \mathrm{C}$ for $15 \mathrm{~min}$ at $16,000 \mathrm{~g}$. Aliquots of $50 \mu 1$ were applied to a reversedphase HPLC system using a $\mathrm{C}_{18}$ Shimadzu column (Shimadzu, Japan) at $260 \mathrm{~nm}$ with a mobile phase containing $60 \mathrm{mM} \mathrm{KH}_{2} \mathrm{PO}_{4}, 5$ $\mathrm{mM}$ tetrabutylammonium chloride, $\mathrm{pH} 6.0$, in $30 \%$ methanol according to a previously described method (28). The adenosine peak was identified by its retention time and by comparison with standards. The ectoadenosine deaminase activity was measured by the decrease in the adenosine peak and by the appearance of inosine and hypoxanthine peaks. The enzyme activity was expressed by the difference between initial (ADi) and final adenosine (ADf) concentration at the time of incubation per mg of protein $(\Delta[\mathrm{ADi}]$ $[\mathrm{ADf}] / \mathrm{mg}$ protein). The addition of dipyridamole (a classical inhibitor of adenosine uptake) did not modify the extracellular adenosine concentration. Spontaneous deamina- 
tion of adenosine was not detected at any time.

\section{Cellular protein determination}

After the assays, the Sertoli cell monolayers were digested with $0.5 \mathrm{~N} \mathrm{NaOH}$ and total protein was measured by the method of Lowry et al. (29).

Figure 1. Time course of ATP, ADP and AMP hydrolysis. $\mathrm{Ca}^{2+}$ ATP, $\mathrm{Ca}^{2+}$-ADP and $\mathrm{Mg}^{2+}$-AMP were incubated with Sertoli cell monolayers as described in $\mathrm{Ma}$ terial and Methods. The data shown were from an experiment carried out in quadruplicate. Data are reported as means \pm SEM
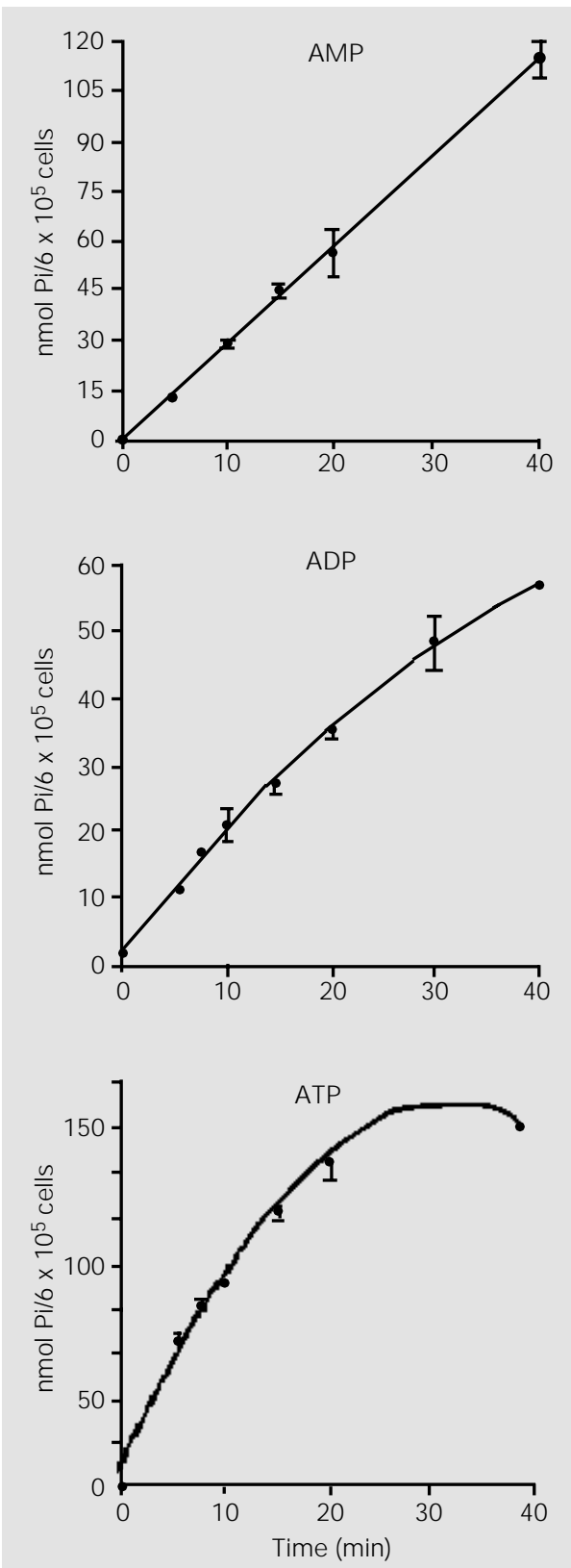

\section{Statistical analysis}

The mean \pm SEM data for groups of three or four experiments were analyzed by ANOVA and the post hoc Student-Newman-Keuls test using the statistical program SPSS 6.0 for Windows.

\section{Results and Discussion}

\section{ATP, ADP and AMP hydrolysis}

Sertoli cell cultures promoted ATP, ADP and AMP hydrolysis that was linear for at least 20 min (Figure 1). One possible problem in the detection of apyrase activity (ATP and ADP hydrolysis) in most sources is the interference of 5'-nucleotidase, which may cause an overestimation of ATPase and ADPase activity (30). The procedure used in the present study to avoid this problem was the limitation of both ATP and ADP hydrolysis to less than $10 \%$. In addition, all mammalian ecto-5'-nucleotidase activities described are strongly inhibited by ATP and ADP in the low micromolar range (31). ATP diphosphohydrolase (apyrase) is an enzyme able to promote the removal of two phosphate groups of ATP but of only one phosphate group of ADP. This enzyme presents divalent cation dependence and can be stimulated by $\mathrm{Ca}^{2+}$ and $\mathrm{Mg}^{2+}(12,15,30,32)$. The ecto-5'-nucleotidase can also be stimulated by $\mathrm{Mg}^{2+}(14,31)$ but this activation was lower than the apyrase activation $(26.3 \pm 5 \%$ for the ecto-5'-nucleotidase activation and 1490 $\pm 84 \%$ for the apyrase activation in relation to the control). In the presence of $2 \mathrm{mM}$ EDTA, ATP and ADP hydrolysis was practically negligible and AMP hydrolysis was lower than control (without the addition of divalent cations) (Figure 2). Thus, the enzymes responsible for the hydrolysis of ATP, ADP and AMP in Sertoli cells could be cation activated. No significant differences were observed in enzymatic activation by different cations at the different concentra- 


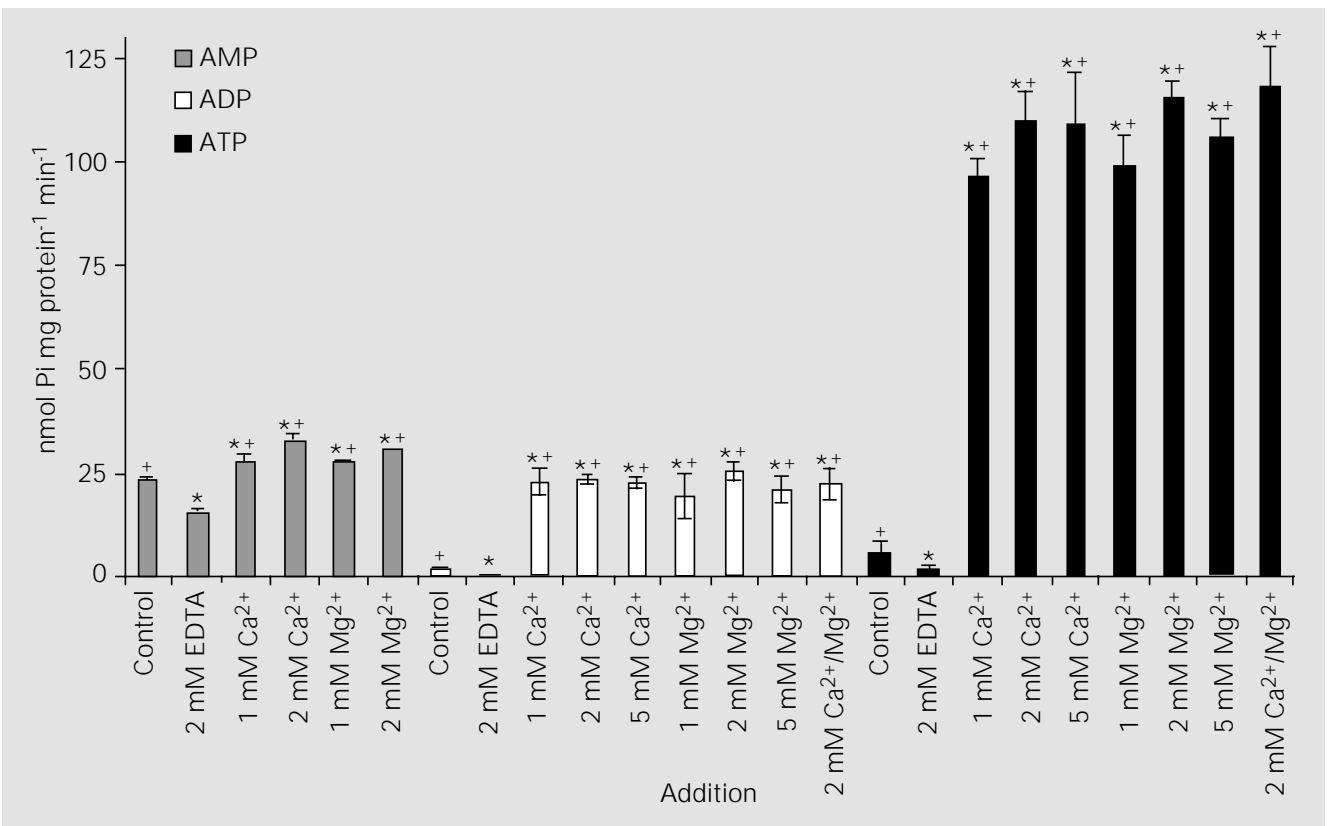

tions tested for ATP, ADP and AMP hydrolysis (Figure 2). This result indicates that maximal activation of the apyrase and ecto5 '-nucleotidase activities is possible with 2 $\mathrm{mM}$ or less of both cations tested. No additive effects were observed when the two divalent cations tested were added at the same time to the reaction medium, suggesting that both $\mathrm{Ca}^{2+}$ and $\mathrm{Mg}^{2+}$ are competing for the same activation site. It is important to note that there was a parallel profile of activation for all substrates (ATP, ADP and AMP) with each cation added. Based on these results, we established as optimal conditions for measuring the ectonucleotidase activities the ratio of $1 \mathrm{mM} / 2 \mathrm{mM}$ for the nucleotides/divalent cation. In this way the ectonucleotidase activities were measured in the physiological extracellular range of divalent cations and nucleotides.

\section{A single active site}

ATP and ADP hydrolysis could be catalyzed by an ATP diphosphohydrolase (apyrase) or by enzyme combinations able to mimic apyrase activity. To show that ATP and ADP hydrolysis occurs due to an apy-

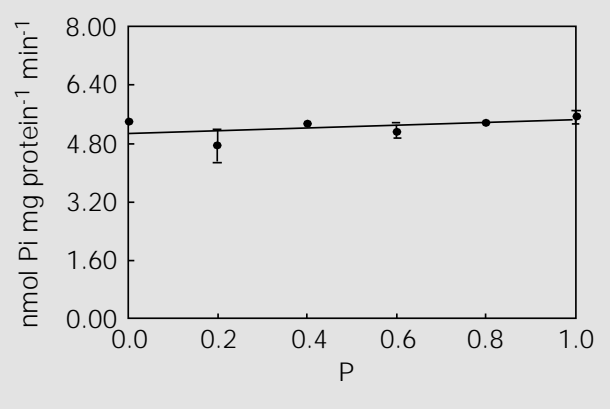

rase and that one active site is able to hydrolyze the two substrates, we used the Chevillard competition plot used by Kettlun et al. (32) to characterize a human placental ATP diphosphohydrolase. To assay the combination of substrate concentrations in a Chevillard competition plot (26) we chose concentrations at which the rate of hydrolysis was the same when either ATP or ADP was used as substrate. The $P$ values ranged from 0 to 1 . The horizontal straight line obtained in the competition plot (Figure 3 ) indicates a constant hydrolysis rate at all substrate combinations tested and the interpretation is that the hydrolysis of both substrates (ATP and ADP) occurs at the same active site of a single enzyme.
Figure 2. Cation dependence on ectonucleotidase activities. Sertoli cells were incubated with the reaction medium plus $1 \mathrm{mM}$ AMP (gray bars), $1 \mathrm{mM} \mathrm{ADP}$ (white bars), and $1 \mathrm{mM}$ ATP (black bars) plus cations or EDTA, as indicated. The data are representative of three different experiments: mean \pm SEM $(N=$ 4) of one typical experiment. $* \mathrm{P}<0.05$ compared to the control group; $+P<0.05$ compared to the 2 mM EDTA group (StudentNewman-Keuls test).

Figure 3. The competition plot. The concentration at which the velocities were the same for ATP and ADP was chosen for the Chevillard plot. The assay conditions are described in $\mathrm{Ma}$ terial and Methods. The incubation time was $10 \mathrm{~min}$; substrate $A$ (ADP) at $P=0$ was $0.1 \mathrm{mM}$ and substrate $B$ (ATP) at $P=1$ was $0.04 \mathrm{mM}$. Data represent an experiment carried out in quintuplicate. The values are the mean \pm SEM. No significant difference was found between different points. 
Figure 4. Eadie-Hofstee plots of ATP, ADP and AMP hydrolysis. Reaction rate was measured by released $\mathrm{Pi}$ as described in $\mathrm{Ma}$ terial and Methods. Results were obtained with a nucleotide concentration ranging from 15 to $2000 \mu \mathrm{M}$ for each substrate. Data were plotted using EadieHofstee plots and with the inset of nonlinear regression for three substrates. Best-fit analysis indicated a linear relationship. Plots are for representative experiments carried out in quadruplicate. The data for the nonlinear regression plot are reported as mean $\pm \mathrm{SEM}$. $V$ is nmol Pi mg protein-1 $\mathrm{min}^{-1}$ and [S] is the substrate concentration in $\mathrm{mM}$.

\section{Kinetic parameters of ATPase, AD Pase and AMPase activities}

$\mathrm{Ca}^{2+}$-ATP and $\mathrm{Ca}^{2+}$-ADP hydrolysis was determined at ATP and ADP concentrations
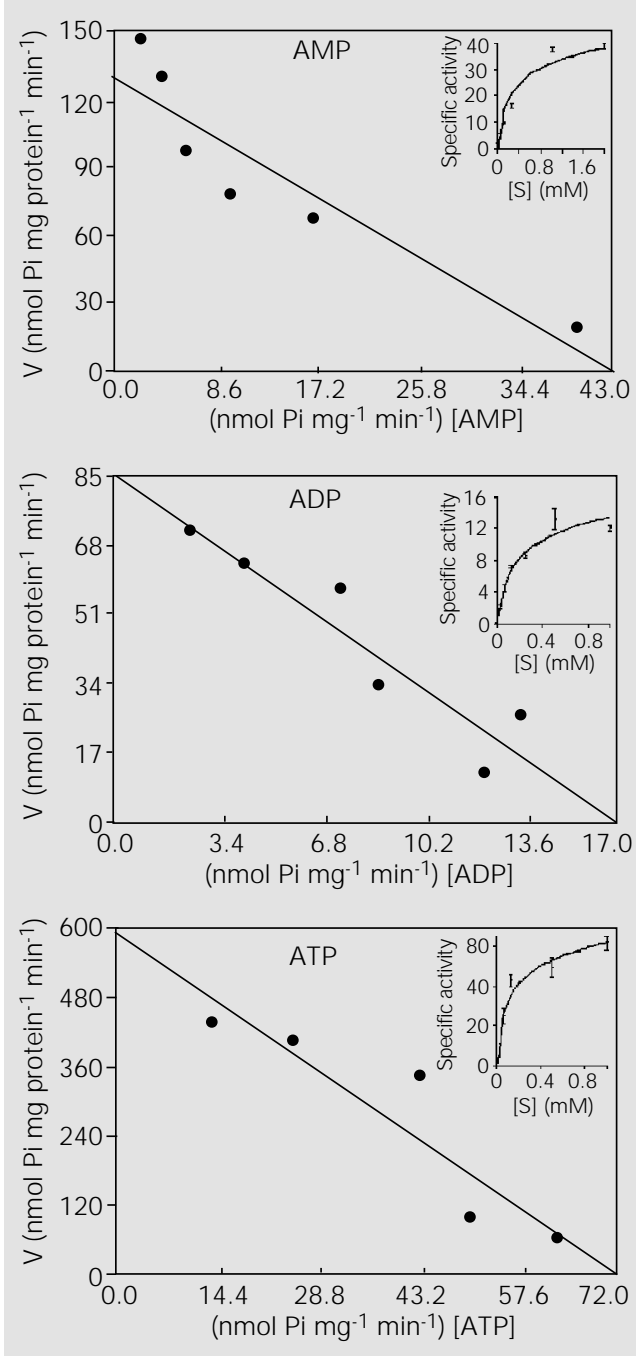

Table 1. Kinetic parameters for ATP, ADP and AMP hydrolysis.

\begin{tabular}{lcc}
\hline Enzyme activity & $\mathrm{K}_{\mathrm{m}}(\mu \mathrm{M})$ & $\mathrm{V}_{\max }\left(\mathrm{nmol}\right.$ Pi mg protein $\left.{ }^{-1} \mathrm{~min}^{-1}\right)$ \\
\hline ATPase & $131 \pm 17.4$ & $59.5 \pm 4.6$ \\
ADPase & $110 \pm 29.0$ & $15.4 \pm 0.5$ \\
AMPase & $410 \pm 73.4$ & $43.3 \pm 7.7$ \\
\hline
\end{tabular}

The kinetic constants were determined using linear regression analysis applied to the data in Figure 4. The values of $K_{m}$ and $V_{\max }$ are the mean \pm SEM of four experiments for ATPase and of three experiments for ADPase and AMPase activities. The mean values of the kinetic parameters did not differ significantly $(P<0.01)$. ranging from 15 to $1000 \mu \mathrm{M}$ for each substrate. $\mathrm{Mg}^{2+}$-AMP hydrolysis was determined at AMP concentrations ranging from 15 to $2000 \mu \mathrm{M}$. The results (Figure 4, inset) indicated that all the enzymatic activities increased with increasing nucleotide concentrations until saturation with $1 \mathrm{mM}$ substrate. The Eadie-Hofstee plot for the hydrolysis of ATP, ADP and AMP is shown in Figure 4 . The Michaelis constant $\left(K_{\mathrm{m}}\right.$, app) (Table 1) calculated by linear regression from the results in Figure 4 was closely similar for ATP and ADP hydrolysis (131 \pm 17.4 and $110 \pm 29 \mu \mathrm{M}$, respectively). It is important to note that a similar $K_{\mathrm{m}}$ value for both substrates is also a characteristic of other apyrases described in the literature $(15,30)$. The Sertoli cell cultures were able to hydrolyze other di- and triphosphate nucleosides such as GTP, GDP, ITP and IDP (data not shown). The hydrolysis of different di- and triphosphate nucleotides is another important characteristic of apyrases from various sources $(12,15,16,30)$. AMP hydrolysis has a calculated $K_{\mathrm{m}}$ of $410 \pm 73 \mu \mathrm{M}$ (Table 1). All ecto5'-nucleotidases described have $K_{\mathrm{m}}$ values in the micromolar range (31). Variations in kinetic data could be the result of speciesand/or tissue-specific forms of the enzyme, analysis of impure preparations or of variations in the assay conditions (31). The IMP and GMP hydrolysis was only 33 and $25 \%$ of AMP hydrolysis (12 and $8 \mathrm{nmol} \mathrm{Pi} \mathrm{mg} \mathrm{pro-}$ tein $^{-1} \min ^{-1}$, respectively) under the same conditions. The AMP substrate preference is another characteristic of ecto-5'-nucleotidase of several tissues (31). These results indicate that the extracellular AMP hydrolysis occurring in Sertoli cells is performed by an ecto5 '-nucleotidase.

\section{Cellular integrity}

The lack of intracellular LDH release during the assays indicated the cellular integrity of cultures. The Sertoli cells remained intact during $40 \mathrm{~min}$ of incubation in the 
reaction medium. Only $5 \%$ of LDH activity of lysed cells ( $1.33 \pm 0.19 \mathrm{U} / \mathrm{mg}$ protein) was measured during $40 \mathrm{~min}$ of incubation. In this way the participation of cytosolic enzymes in extracellular nucleotide hydrolysis was excluded.

\section{Adenosine deaminase activity}

It has been previously demonstrated that testis tissue contains adenosine deaminase mRNA (33) and we have investigated whether this enzyme is present on the plasma membrane surface of Sertoli cells and its capacity to degrade extracellular adenosine. Sertoli cells are able to degrade the extracellular adenosine by an ectoadenosine deaminase activity (Figure 5). The ectoadenosine deaminase is a key enzyme in purine metabolism that catalyzes the irreversible transformation of adenosine and 2'-deoxyadenosine to inosine and 2'-deoxyinosine, respectively. Its enzymatic activity is homogeneously distributed along the cell surface in some cells (34). The Sertoli cell ectoadenosine deaminase activity was linear up to 60 min of incubation (Figure 5) and had a specific activity of $1.52 \pm 0.13 \mathrm{nmol}$ adenosine $\mathrm{mg}$ protein ${ }^{-1} \mathrm{~min}^{-1}$. The decrease in adenosine levels in the extracellular medium was of the same order of magnitude as the increase in inosine and hypoxanthine (data not shown) and this demonstrates that the adenosine decrease is a result of adenosine deaminase activity rather than of cellular adenosine uptake. The presence of dipyridamole $(10 \mu \mathrm{M})$, a classical inhibitor of adenosine uptake (35), in the ADA buffer did not alter the extracellular adenosine concentration but caused $30 \%$ inhibition of ectoadenosine deaminase activity. A possible explanation for this result is the participation of ectoadenosine deaminase in a protein complex that can have multiple functions such as catalytic deamination activity, coupled with adenosine receptors and with selective channels by uptake of extracellular adenosine
$(34,36)$. The presence of dipyridamole can alter the conformation of the protein complex with a modification in the enzymatic activity.

\section{The physiological role}

The physiological role of ectonucleotidases is unknown but it has been speculated that their function could be the control of extracellular concentration of purines. The modulation of the levels of different nucleotides may involve "cross-talking" between the diverse pathways activated in purinergic receptor subtypes. The general way to control the concentration of adenine nucleotides is the sequential activity of ecto-ATPases, ecto-ATP diphosphohydrolases (apyrase) and ecto-5'-nucleotidases $(12-17,19,20,30)$. The adenosine released from cells or resulting from extracellular ATP hydrolysis can be deaminated by the ectoadenosine deaminase activity, producing inosine $(18,34,36)$.

Adenosine and its antagonists, such as caffeine, have been long postulated to influence the male reproductive system. Several reports have demonstrated the presence of adenosine receptors in Sertoli cells $(10,11)$ and their modulation by adenosine and different adenosine analogues $(4,8,9)$. The purinoreceptor subtype $\mathrm{P}_{2 \mathrm{Y} 2}$ is present in these cells (5) and its modulation by ATP has been well demonstrated (5-7). In Sertoli

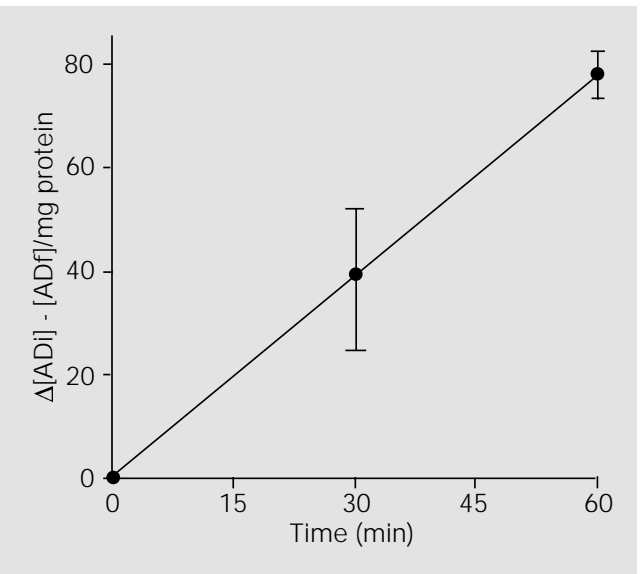

Figure 5. Ectoadenosine deaminase activity. Adenosine deaminase was determined as described in Material and Methods. The enzymatic activity is reported as the difference between the initial and final concentration of adenosine/mg of protein $(\Delta[\mathrm{ADi}]$ - $[\mathrm{ADf}] \mathrm{mg}$ protein). The values are the mean \pm SEM for a representative experiment carried out in quadruplicate. 
cells, extracellular ATP and adenosine can modulate the hormonal response to $\mathrm{FSH}$, decreasing cAMP levels (4,5,8-10), and can regulate anionic (6) and transferrin secretion (7) and the intracellular levels of $\mathrm{Ca}^{2+}$ by inositol phospholipid turnover (5). Thus, the control of extracellular levels of adenosine nucleotides is of high physiological relevance. However, the mechanism controlling purine concentrations in testicular tissue is poorly known. We show in this study that Sertoli cells were able to hydrolyze ATP and ADP (Figure 1) and that only one active site is responsible for the hydrolysis of the two nucleotides (Figure 3). Barbacci et al. (22) identified and characterized one possible ecto-ATPase in rat Sertoli cells. The $K_{\mathrm{m}}$ calculated for the possible ecto-ATPase is the same we found for ATP and ADP hydrolysis (Table 1), indicating that one enzyme is responsible for the hydrolysis of the two nucleotides. The results obtained in the competition plot confirm this hypothesis. The cation requirements demonstrated by Barbacci et al. (22) for ATP hydrolysis are equal to those for ADP hydrolysis demonstrated by us (Figure 2). On the other hand, our results cannot exclude the co-expression of two enzymes (a fact demonstrated in the rat brain) (37) because the ATP hydrolysis demonstrated by Barbacci et al. (22) was slightly inhibited by ADP. In other tissues it has been postulated that the control of extracellular nucleotide concentration is due to the action of enzymatic complexes with the possible participation of two or more ectoenzymes (21). The most obvious physiological role for apyrase in Sertoli cells, in analogy to other tissues, is to participate in an "enzyme chain" together with a 5'-nucleotidase for the complete hydrolysis of ATP to adenosine.

AMP hydrolysis occurs through the action of an ecto-5'-nucleotidase releasing adenosine that could create a secondary signal for $\mathrm{P}_{\mathrm{A} 1}$ receptors. The Sertoli cell ecto-
5 '-nucleotidase has proved to be cation activated and in the presence of normal extracellular concentrations of $\mathrm{Ca}^{2+}$ and $\mathrm{Mg}^{2+}$ (1-2 $\mathrm{mM}$ ) its activity is increased compared to the control activity (without cation addition) and the 2 mM EDTA group (Figure 2). The $K_{\mathrm{m}} /$ $V_{\max }$ values (Table 1) and the substrate preference are in accordance with the other characteristics of ecto-5'-nucleotidase from several tissues (31).

In order to terminate the purine extracellular cascade of nucleotides and nucleosides, the ectoadenosine deaminase produces inosine that can be taken up and/or degraded by the cells. We have demonstrated that Sertoli cells have an ectoadenosine deaminase activity with the same buffer requirement as for other cells (Figure 5) (28). In analogy, this enzyme can participate together with an ATP diphosphohydrolase and the ecto-5'nucleotidase in the control of the extracellular adenosine levels and eliminate the purine cascade.

The physiological control of ectonucleotidase activities is unknown. Moreover, Franco et al. $(34,36)$ have demonstrated that some ectoenzymes can play the role of one enzyme and that of a receptor which can be internalized when the substrate is in its active site. Another possibility is the co-localization of ectoenzyme and receptor at the same site on the plasma membrane. Receptor desensitization can occur by endocytosis of membrane fragments where the ectoenzyme and the receptor in question are present. Some authors have shown that ectonucleotidases can lose their activities in response to a cell signal $(38,39)$ and that ectonucleotidase activities initially localized on the membrane surface are internalized into endoplasmic vesicles (40).

In experiments currently underway, we are searching for a possible modulation in ectonucleotidase activities by hormones that act on Sertoli cells, possibly representing a fine control of these enzymatic activities. 


\section{References}

1. El-Moatassim C, Dornand J \& Mani J (1992). Extracellular ATP and cell signalling. Biochimica et Biophysica Acta, 1134: 31-45.

2. Dubyak GR \& El-M oatassim C (1993). Signal transduction via P2-purinergic receptors for extracellular ATP and other nucleotides. American J ournal of Physiology, 265: C577-C606.

3. Ralevic V \& Burnstock G (1998). Receptors for purines and pyrimidines. Pharmacological Reviews, 50: 413-492.

4. Conti M, Boitani C, DeManno DA, Migliaccio S, Monaco L \& Szymeczek C (1989). Characterization and function of adenosine receptors in the testis. Annals of the New York Academy of Sciences, 564: 39-47.

5. Filippini $A$, Riccioli $A$, Cesaris $P$ de, Paniccia R, Teti A, Stefanini M, Conti M \& Ziparo E (1994). Activation of inositol phospholipids and calcium signaling in rat Sertoli cells by P2 purinergic receptors: modulation of follicle-stimulating hormone responses. Endocrinology, 134: 1537-1545.

6. Ko WH, Chan HC, Chew SB \& Wong PYD (1998). Regulated anion secretion in the epithelia from Sertoli cells of immature rats. J ournal of Physiology, 512: 471-480.

7. Meroni SB, Cánepa DF, Pellizari EH \& Schteingart HF (1998). Effects of purinergic agonists on aromatase and gammaglutamyl transpeptidase activities and on transferrin secretion in cultured Sertoli cells. J ournal of Endocrinology, 157: 275283.

8. Monaco L, DeManno DA, Martin MW \& Conti M (1988). Adenosine inhibition of the hormonal response in the Sertoli cell is reversed by pertussis toxin. Endocrinology, 122: 2692-2698.

9. Monaco L, Toscano MV \& Conti M (1984). Purine modulation of the hormonal response of the rat Sertoli cell in culture. Endocrinology, 115: 1616-1624.

10. Stiles GL, Pierson G, Sunay $S \&$ Parsons WJ L (1986). The rat testicular Al adenosine receptor-adenylate cyclase system. Endocrinology, 119: 1845-1851.

11. Rivkees SA (1994). Localization and characterization of adenosine receptor expression in rat testis. Endocrinology, 135: 2307-2313.

12. Battastini AMO, Oliveira EM, Moreira CM, Bonan CD, Sarkis J J F \& Dias RD (1995). Solubilization and characterization of an ATP diphosphohydrolase (EC 3.6.1.5) from rat brain synaptic plasma mem- branes. Biochemistry and Molecular Biology International, 37: 209-219.

13. Candinas $D$, Koyamada N, Miyatake $T$, Siegel J, Hancock WW, Bach FH \& Robson SC (1996). Loss of rat glomerular ATP diphosphohydrolase activity during reperfusion injury is associated with oxidative stress reactions. Thrombosis and Haemostasis, 76: 807-812.

14. Danvish A, Pomerantz WR, Zografides $P \&$ Metting P (1996). Contribution of cytosolic and membrane-bound 5'-nucleotidase to cardiac adenosine production. American J oumal of Physiology, 271: H2162H2167.

15. Frasseto SS, Dias RD \& Sarkis J J F (1993). Characterization of an ATP diphosphohydrolase activity (apyrase, EC 3.6.1.5) in rat blood platelets. Molecular and Cellular Biochemistry, 129: 47-55.

16. Ishikawa $\mathrm{H}$, Tamiya $\mathrm{T}$, Tsuchiya $\mathrm{T} \&$ Matsumoto J (1984). A novel ATP-ADPase from Mimosa pulvinus. Comparative Biochemistry and Physiology, 78B: 59-61.

17. Kohring $\mathrm{K} \&$ Zimmermann H (1998). Upregulation of ecto-5'nucleotidase in human neuroblastoma SH-SYY cells on differentiation by retinoic acid or phorbolester. Neuroscience Letters, 258: 127130.

18. Lloyd HGE \& Fredholm BB (1995). Involvement of adenosine deaminase and adenosine kinase in regulating extracellular adenosine concentration in rat hippocampal slices. Neurochemistry International, 26: 387-395.

19. Minelli $A$, Moroni $M$, Trinari $D \&$ Mezzasoma I (1997). Hydrolysis of extracellular adenine nucleotides by equine epididymal spermatozoa. Comparative Biochemistry and Physiology, 117B: 531-534.

20. Node $K$, Kitakaze $M$, Minamini $T$, Michihiko $T$, Inoue $M$, Hori $M \&$ Kamada $T$ (1997). Action of ecto-5'-nucleotidase by protein kinase $C$ and its role in ischaemic tolerance in canine heart. British J ournal of Pharmacology, 120: 273-281.

21. Grobben B, Anciaux K, Roymans D, Stefan C, Bolen M, Esmans EL \& Slegers $H$ (1999). An ecto-nucleotide pyrophosphatase is one of the main enzymes involved in the extracellular metabolism of ATP in rat C6 glioma. J ournal of Neurochemistry, 72: 826-834.

22. Barbacci E, Filippini $A$, Cesaris $P$ De \& Ziparo $E$ (1996). Identification and characterization of an ecto-ATPase in rat Sertoli cells. Biochemical and Biophysical Research Communications, 222: 273-279.
23. Rocha AB, Guma FCR, Casali EA, Scherer GS, Achaval ME \& Bernard EA (1997). Influence of the biomatrix on the response of Sertoli cells to FSH. Archives of Physiology and Biochemistry, 105: 1-5.

24. Palombi $F \&$ Di Carlo C (1988). Alkaline phosphatase is a marker for myoid cells in cultures of peritubular and tubular tissue. Biology of Reproduction, 39: 1101-1109.

25. Chan K, Delfert D \& J unger KD (1986). A direct colorimetric assay for the $\mathrm{Ca}^{2+}$ ATPase activity. Analytical Biochemistry, 157: 375-380.

26. Chevillard $C$, Cárdenas $M L \&$ CornishBowden A (1993). The competition plot: a simple test of whether two reactions occur at the same active site. Biochemical J ournal, 289: 599-604

27. Trams GE \& Lauter CJ (1974). On the sidedness of plasma membrane enzymes. Biochimica et Biophysica Acta, 345: 180-197.

28. Voelter W, Zech K, Arnold P \& Ludwig G (1980). Determination of selected pyrimidines, purines and their metabolites in serum and urine by reversed-phase ionpair chromatography. J ournal of Chromatography, 199: 345-354.

29. Lowry OH, Rosebrough NJ, Farr AL \& Randall RJ (1951). Protein measurement with the Folin phenol reagent. J ournal of Biological Chemistry, 193: 265-275.

30. Sarkis J J F \& Salto C (1991). Characterization of a synaptosomal ATP diphosphohydrolase from the electric organ of Torpedo marmorata. Brain Research Bulletin, 26: 871-876.

31. Zimmermann H (1992). 5'-Nucleotidase: molecular structure and functional aspects. Biochemical J ournal, 285: 345-365.

32. Kettlun AM, Alvarez $A$, Quintar $R$, Valenzuela MA, Collados L, Aranda E, Banda A, Chayet $L$, Chiong $M$, Mancilla $M$ \& Traverso-Cori A (1994). Human placental ATP-diphosphohydrolase biochemical characterization, regulation and function. International J ournal of Biochemistry, 26: 437-488.

33. Meng J , Zhang F, Huhtaniemi I \& Pakarinen $P$ (1997). Characterization and developmental expression of a testis-specific adenosine deaminase mRNA in the mouse. J ournal of Andrology, 18: 88-95.

34. Franco R, Mallol J, Casadó V, Lluis C, Canela El, Saura C, Blanco J \& Ciruela F (1998). Ecto-adenosine deaminase: an ecto-enzyme and costimulatory protein acting on a variety of cell surface receptors. Drug Development Research, 45: 
261-268.

35. Meghii P \& Newby AC (1990). Sites of adenosine formation, action and inactivation in the brain. Neurochemistry International, 16: 227-232.

36. Saura CA, Mallol J, Canela El, Lluis C \& Franco R (1998). Adenosine deaminase and $\mathrm{Al}$ adenosine receptors internalize together following agonist-induced receptor desensitization. J ournal of Biological Chemistry, 273: 17610-17617.
37. Kegel $B$, Braun $N$, Heine $P$, Maliszewski CR \& Zimmermann H (1997). An ectoATPase and an ecto-ATP diphosphohydrolase are expressed in rat brain. Neuropharmacology, 36: 1189-1200.

38. Robson SC, Kaczmarek E, Siegel J B, Candinas D, Kosiak K, Millan M, Hancock WW \& Bach FH (1997). Loss of ATP diphosphohydrolase activity with endothelial activation. Journal of Experimental Medicine, 185: 153-163.
39. Kobayashi T, Okada T, Saz EG del \& Seguchi H (1997). Internalization of ectoATPase activity in human neutrophils upon stimulation with phorbol ester or formyl peptide. Histochemistry and Cell Biology, 107: 353-363.

40. Biederbick A, Rose S \& Elsässer H (1999). A human intracellular apyrase-like protein LALP70, localizes to lysosomal/autophagic vacuoles. J oumal of Cell Science 112: 2473-2488. 